\title{
Armitage, David; Guldi, Jo Manifesto pela História
}

Fabricio Leal de Souza ${ }^{*}$

Tradução de Modesto Florenzano. Belo Horizonte: Autêntica, 2018. 190 p.

Manifesto pela História é uma apologia da história de longa duração que reacende as discussões sobre o lugar dos historiadores na sociedade contemporânea. Publicado originalmente em 2014 pela Cambridge University Press (Armitage; Guldi, 2014), o livro foi prontamente disponibilizado na internet, o que permitiu sua rápida difusão. Após as traduções para os idiomas chinês, coreano, espanhol, italiano, japonês, turco e russo, finalmente está disponível para o leitor brasileiro a versão publicada pela editora Autêntica. ${ }^{1}$

Os quatro capítulos que estruturam o livro convergem para a ideia de que o mundo contemporâneo está mergulhado naquilo que os autores chamam de short-termism (visão de curto prazo). Diante do crescimento exponencial do big data (grandes volumes de dados), da fragmentação da história e do imediatismo das ideias que orientam as políticas públicas, a elaboração de pensamentos e projetos de longo prazo seria cada vez mais inviável. Esse panorama chega mesmo a assumir contornos apocalípticos quando os autores o relacionam a três grandes problemas globais: as mudanças climáticas, a governança mundial e a desigualdade social.

A predominância do pensamento de curto prazo na disciplina da história teria permitido que análises de longo prazo fossem monopolizadas pela economia e pela climatologia, que também teriam assumido o protagonismo de pensar o futuro da humanidade. Em vista disso, Armitage e Guldi conclamam os historiadores a lutar contra o curto prazo, por eles denunciado como o inimigo do mundo contemporâneo.

Em tempos de incertezas, os autores defendem que a história é o conhecimento capaz de iluminar um caminho seguro para o futuro. É nesse sentido

* Doutorando, Universidade de São Paulo, Programa de Pós-Graduação em História Social, São Paulo, SP, Brasil. contato@fabricio.cc <https://orcid.org/0000-0002-4478-3647> 
que, no primeiro capítulo, intitulado "Avançar olhando para trás: o surgimento da longue durée", há uma releitura do conceito de longa duração que Fernand Braudel apresentou no famoso texto "História e Ciências Sociais: a longa duração" (Braudel, 1965). Na tentativa de inserir os historiadores nos debates sobre o destino apocalíptico da humanidade, prenunciado pela climatologia e pela economia, os autores defendem que a história deveria concentrar-se em apresentar pensamentos utópicos de longa duração e "modelos de produção agrícola e de consumo" como alternativas ao capitalismo (p. 49). Desse modo, o futuro não ficaria destinado ao livre-arbítrio.

Via de regra, a história analisa aquilo que aconteceu no passado e não aquilo que poderia ter acontecido. Em nome da defesa de um futuro ameaçado pelas mudanças climáticas antropogênicas, os autores argumentam favoravelmente à utilização do pensamento contrafactual, envolvendo a elaboração de teorias hipotéticas e suposições aplicadas a um passado que poderia ter sido, no intuito de criar cenários alternativos para o presente e o futuro. E se a máquina a vapor não tivesse sido inventada? As implicações que essa concepção desencadeia na prática historiográfica são complexas e, por isso mesmo, ela mereceria uma abordagem mais aprofundada em vez de uma simples menção.

Fernand Braudel afirmava que "a história é a soma de todas as histórias possíveis" e que seria um erro "escolher uma destas histórias com a exclusão das outras” (Braudel, 1965, p. 272). Por sua vez, Manifesto pela História privilegia a história de longa duração, exclui temporalidades que considera desnecessárias e estabelece prerrogativas para os temas estruturais. A história, ética e comprometida com a solução dos problemas globais, romperia as fronteiras nacionais para atuar como um "instrumento de reforma e um meio para delinear futuros alternativos” (p. 26). É uma perspectiva que se distancia dos frequentes diálogos que a história estabelece com as ciências sociais e fica aquém de apresentar saídas palpáveis aos problemas que exigem respostas para temporalidades curtas.

O segundo capítulo, intitulado "O passado breve: ou, a retirada da longue durée”, aborda a transição, que teria ocorrido na década de 1960, da história de longa duração para uma de curta duração. O ponto mais relevante e controverso do capítulo é a afirmação de que a história se afastou dos estudos de longa duração em virtude da micro-história, rotulada de "escola fundamentalista redutora de horizontes temporais" (p. 70). No caso específico dos Estados Unidos, os autores atribuem à micro-história e aos estudos dos 
movimentos dos direitos civis, aos protestos contra a guerra do Vietnã e ao feminismo a responsabilidade por desviar a atenção das grandes narrativas e dos temas estruturais de longa duração. A redução da escala seria a responsável pelo abandono dos exemplos morais em troca dos acontecimentos particulares. Como resultado, a história teria sido conduzida para pesquisas irrelevantes, afastando-se da participação e direção de instituições públicas, tanto quanto da elaboração de políticas para o futuro. Para reaver o prestígio perdido, os autores afirmam que se faz necessário redefinir o "tipo de narrativa histórica de que mais temos necessidade hoje" (p. 53).

A redução da escala e o uso intensivo dos arquivos também seriam os responsáveis pela alteração do processo de formação dos jovens historiadores e da percepção que eles têm sobre o passado e o futuro. Ao citarem estatísticas de 8 mil teses de doutorado defendidas nos Estados Unidos entre 1880 e 2012, os autores procuraram demonstrar que houve um distanciamento da longa duração. No entanto, o gráfico por eles utilizado (p. 67) ilustra justamente o contrário: a partir da década de 1960, é possível observar um crescimento contínuo, chegando ao século XXI com uma concentração das pesquisas entre 75 e 100 anos. Embora ainda esteja distante da temporalidade prevista para ser considerada de longa duração, no auge da micro-história é possível observar uma ampliação em lugar de uma retração.

"O longo e o breve: mudança climática, governança e desigualdade a partir da década de 1970" é o título do terceiro capítulo e trata de questões estruturais analisadas por economistas e climatologistas, mobilizadas num passado de longa duração para afirmar teses e propor advertências para um mundo viável no futuro. No caso da climatologia, os dados coletados no passado para mostrar as intensas mudanças climáticas antropogênicas são dados históricos e não proposições sobre "novos modelos de ecossistemas" (p. 99). A mesma perspectiva de longa duração é sugerida para se pensar as diferentes configurações da sociedade ao longo da história e contribuir com o debate sobre a governança global. Os autores destacam, aí, o estudo do economista Thomas Piketty que, ao analisar a desigualdade no longo prazo, concluiu que o capitalismo aumentou dramaticamente a concentração de renda (Piketty, 2014).

Por fim, o quarto capítulo, intitulado "Grandes questões, big data", reconhece que há abundância de dados no mundo contemporâneo, notadamente a partir da Segunda Guerra Mundial. A produção e o acúmulo de grandes quantidades de dados governamentais referentes ao clima, à 
economia e à energia ainda não teriam recebido a devida atenção dos estudos de longa duração. Na medida em que há esse crescimento do big data, os historiadores estariam cada vez mais forçados a manusear tais dados, condição que impõe às universidades uma formação que permita o desenvolvimento e aquisição de técnicas e métodos apropriados. Para exemplificar, os autores apresentam uma relação de ferramentas que podem contribuir com as análises históricas, como é o caso do Paper Machines, desenvolvido pela própria Jo Guldi, o qual permite a extração e visualização de dados contidos em grandes quantidades de textos. ${ }^{2}$

As ideias de David Armitage e Jo Guldi foram alvo de intensas críticas, com destaque para o dossiê "La longue durée en débat" que a revista Annales organizou em 2015. Lynn Hunt, por exemplo, afirma que os autores negligenciaram as mudanças próprias da disciplina e se equivocaram ao sustentar que a micro-história é a responsável pela "crise moral” da história. Ademais, o retorno aos temas estruturais de longa duração poderia conceder privilégios às elites políticas em detrimento dos múltiplos campos e sujeitos (Hunt, 2015).

O diagnóstico que Manifesto pela História oferece é a necessidade de transformar os grandes problemas globais nos motores da história. Os mitos da modernização e do liberalismo precisariam ser abalados pelos estudos de longa duração para reconectar o passado com o futuro da humanidade. É com essa finalidade que os autores gritam “uni-vos!". Mas após remexermos nos mais recônditos arquivos e revelarmos histórias e personagens surpreendentes, retornaremos ainda aos grandes temas e metanarrativas?

\section{REFERÊNCIAS}

ARMITAGE, David; GULDI, Jo. The History Manifesto. Cambridge: Cambridge University Press, 2014.

BRAUDEL, Fernand. História e Ciências Sociais: a longa duração. Revista de História, São Paulo, v. 30, n. 62, p. 261-294, 1965.

ÉDITORIAL: La longue durée en débat. Annales. Histoire, Sciences Sociales, Paris, v. 2, n. 70, p. 285-287, 2015.

HUNT, Lynn. Faut-il réinitialiser l'histoire? Annales. Histoire, Sciences Sociales, Paris, v. 2, n. 70, p. 319-325, 2015.

PIKETTY, Thomas. O capital no século XXI. Tradução Monica Baumgarten de Bolle. Rio de Janeiro: Intrínseca, 2014. 


\section{NOTAS}

${ }^{1} \mathrm{O}$ download da versão inglesa pode ser realizado no site do projeto: http://historymanifesto.cambridge.org/. Acesso em: 31 out. 2018.

${ }^{2}$ Paper Machines é uma extensão para ser usada com o Zotero. Disponível em: http://papermachines.org/. Acesso em: 31 out. 2018.

Resenha recebida em 2 de novembro de 2018. Aprovada em 15 de janeiro de 2019. 